\title{
Editorial for Advanced Health Care Technologies
}

\author{
This article was published in the following Dove Press journal: \\ Advanced Health Care Technologies \\ 29 January 2015 \\ Number of times this article has been viewed
}

\section{Utkan Demirci \\ ShuQi Wang \\ Fatih Inci}

Bio-Acoustic-MEMS in Medicine (BAMM) Laboratory, Stanford University School of Medicine, Radiology Department, Canary Center at Stanford for Cancer Early Detection, Palo Alto, CA, USA

Correspondence: Utkan Demirci Bio-Acoustic-MEMS in Medicine (BAMM) Laboratory, Stanford University School of Medicine, Radiology Department, Canary Center at Stanford for Cancer Early Detection, 3155 Porter Drive, Palo Alto, CA 94304, USA

Email utkan@stanford.edu
Without doubt, science and technologies have tremendously changed the world, so have the health care technologies. In recent human history, we have witnessed that the state-of-the-art health care technologies such as medical imaging, molecular diagnostics, tissue engineering and regenerative medicine, single cell analysis, high throughput DNA sequencing, and rapid screening tests have restructured the medical practice of disease prevention, diagnosis, and treatment. Emerging technologies including bio/nanotechnologies, microfluidics, and single-cell imaging/analysis have created a niche to impact human health care systems, ranging from identifying etiologies, creating new therapeutics, and improving clinical outcomes in both developed and developing countries. We believe that advanced health care technologies hold the promise to prevent, treat, and cure devastating diseases including infectious diseases such as acquired immunodeficiency syndrome (AIDS), tuberculosis, and cancer, thus taking steps towards creating a disease-free world, eliminating poverty and enhancing life quality in the future.

We clearly see the significant role of advanced materials and how they interact with cells and other materials as we enter a phase of advanced biomanufacturing technologies, which have broad applications in the fields of tissue engineering, regenerative medicine, diagnostics, and biomaterials. Novel tools of nanomasonary and micromasonary, enabling high throughput capabilities to manufacture materials with precision, repeatability, and reliability, shaping material properties from femto to microscale, have broad implications for human health, with translatable clinical applications. With this, we welcome you to submit your biomedical research, clinical studies, and reviews associated with Advanced Health Care Technologies. The "Open Access" feature of this journal will help you rapidly disseminate your valuable results across the world.

\section{Disclosure}

Dr U Demirci is a founder of, and has an equity interest in DxNow Inc., a company that is developing microfluidic and imaging technologies for point-of-care diagnostic solutions; and Koek Biotech, a company that is developing microfluidic IVF technologies for clinical solutions. Dr U Demirci's interests were viewed and managed by the Brigham and Women's Hospital and Partners HealthCare in accordance with their conflict of interest policies. 
Advanced Health Care Technologies

Dovepress

\section{Publish your work in this journal}

Advanced Health Care Technologies is an international, peer reviewed, open access journal that provides a unique forum for articles on: point-of-care, health care diagnostics and treatment, bioengineering, biotechnology, biosensing, electronics, clinical/medical science, chemical engineering, materials science, regenerative medicine, micro-/

nano-technologies, and methods and applications for nanoscience and nanotechnology. The manuscript management system is completely online and includes a very quick and fair peer review system, which is all easy to use. Visit http://www.dovepress.com/testimonials.php to read real quotes from published authors.

Submit your manuscript here: http://www.dovepress.com/advanced-health-care-technologies-journal 